\title{
The Effect of Treatment of Type 2 (Insulin Independent) Diabetes Mellitus on Plasma Concentrations of Pancreatic Polypeptide and Glucagon
}

\author{
D. Berger, J. C. Floyd, Jr. and S. B. Pek \\ Department of Internal Medicine, (Division of Endocrinology and Metabolism and the Metabolism Research Unit), \\ The University of Michigan, Ann Arbor, Michigan, USA
}

\begin{abstract}
Summary. The effect of the control of diabetes with diet and insulin upon plasma levels of human pancreatic polypeptide and glucagon was determined in eight patients with Type 2 (insulin independent) diabetes mellitus. The mean \pm SEM fasting plasma glucose was $15.9 \pm 1.3 \mathrm{mmol} / 1$ for 5 days of diet treatment and $5.9 \pm 0.4 \mathrm{mmol} / \mathrm{l}$ for the last 5 days of treatment with diet plus insulin $(\mathrm{p}<0.0001)$; corresponding fasting plasma pancreatic polypeptide levels were $328 \pm 97$ and $247 \pm 71 \mathrm{pg} / \mathrm{ml}(\mathrm{p}<0.05)$ and immunoreactive glucagon levels were $95 \pm 11$ and $62 \pm 6 \mathrm{pg} / \mathrm{ml}(\mathrm{p}<0.005)$. Cooked ground beef was administered on the first day of diet treatment and on the last day of treatment with diet plus insulin; mean maximal rise of pancreatic polypeptide, and total and incremental plasma pancreatic polypeptide response areas were significantly lower following treatment $(\mathrm{p}<0.01)$, as was total area for immunoreactive glucagon $(\mathrm{p}<0.05)$. Normalisation of fasting plasma glucose by short-term treatment with diet plus insulin is associated with decreases in basal and stimulated secretory activity of the pancreatic polypeptide cells in insulin independent diabetes mellitus.
\end{abstract}

Key words: Insulin independent diabetes mellitus, human pancreatic polypeptide, glucagon, control of diabetes, insulin treatment, protein meal.

The ingestion of a protein meal is a potent stimulus for the rapid release of immunoreactive human pancreatic polypeptide (PP) in healthy subjects [1-3]. In a group of patients with Type 2 diabetes mellitus (insulin independent) under treatment with diet plus insulin mean basal plasma level of human PP was elevated [2]. The current investigation was carried out to determine whether short-term control of Type 2 diabetes with diet plus insulin, sufficient to bring fasting plasma levels of glucose into the normal range, would have an effect upon basal and beef meal-stimulated plasma levels of human PP.

\section{Materials and Methods}

\section{Patients}

Eight patients with uncontrolled diabetes mellitus were studied in the Clinical Research Center of University of Michigan Hospital after giving their informed consent. The investigations were performed in accordance with the principles of the Declaration of Helsinki. The clinical data are shown in Table 1. The patients were classified as having Type 2 diabetes because: 1) after a mean known duration of diabetes of 8 years (range 0-16 years), none had had ketonuria or ketoacidosis (only three patients had ever received insulin, each for less than 2 weeks), 2) the age at diagnosis ranged from 26 to 59 years, 3) at this study each had a fasting plasma insulin level in the normal range and an increase after ingestion of beef (mean maximal increase was $17 \mathrm{mU} / 1$ ).

No patient had evidence of circulating antibodies to PP [2] as ascertained by incubation of plasma with ${ }^{125} \mathrm{I}-\mathrm{PP}$ followed by precipitation of plasma proteins with polyethylene glycol [2]. Patients 1,2 , and 5 had received treatment with insulin, and patients 3 and 7 sulphonylureas; therapy had been discontinued 1 week before hospitalisation. At the time of admission six patients had mild to moderate polyuria and polydipsia. Patients 1 and 3 had necrobiosis lipoidica diabeticorum. Except for diabetes, only one patient had a major illness; patient 6 had mild hypertension, treatment for which had been discontinued 10 days before admission. No patient received any medication other than insulin during the study.

\section{Treatment and Testing of Patients}

Upon admission the patients were placed on diets which were calculated to maintain their current weight throughout the hospitalisation; the caloric value of each patient's diet was derived $40 \%$ from carbohydrate, $40 \%$ from fat and $20 \%$ from protein. Following an initial 5 days of study on diet alone (period 1), insulin 
Table 1. Clinical data of patients with Type 2 (insulin independent) diabetes mellitus

\begin{tabular}{|c|c|c|c|c|c|c|c|}
\hline Patient & Sex & $\begin{array}{l}\text { Age } \\
\text { (years) }\end{array}$ & $\begin{array}{l}\text { Ideal } \\
\text { body weight }^{a} \\
(\%)\end{array}$ & $\begin{array}{l}\text { Known duration } \\
\text { of diabetes } \\
\text { (years) }\end{array}$ & $\begin{array}{l}\text { Diet } \\
\text { (kcal/day) }\end{array}$ & $\begin{array}{l}\text { Average } \\
\text { insulin dose } \\
(\mathrm{U} / \text { day })^{\mathrm{b}}\end{array}$ & $\begin{array}{l}\text { Interval between } \\
\text { first and second } \\
\text { beef meal (days) }\end{array}$ \\
\hline 1 & $\mathrm{~F}$ & 26 & 95 & 0 & 1,540 & 23 & 16 \\
\hline 2 & $\mathbf{M}$ & 33 & 86 & 4 & 2,150 & 30 & 17 \\
\hline 3 & $\mathrm{M}$ & 34 & 120 & 4 & 2,155 & 53 & 16 \\
\hline 4 & $\mathbf{M}$ & 44 & 127 & 6 & 1,800 & 17 & 14 \\
\hline 5 & $\mathrm{~F}$ & 51 & 131 & 11 & 1,800 & 55 & 16 \\
\hline 6 & M & 63 & 94 & 16 & 2,100 & 34 & 20 \\
\hline 7 & $\mathbf{F}$ & 67 & 105 & 15 & 1,835 & 35 & 17 \\
\hline 8 & $\mathrm{~F}$ & 68 & 98 & 9 & 1,600 & 34 & 14 \\
\hline
\end{tabular}

a Based on Metropolitan Life Insurance Company tables derived primarily from data of the Build and Blood Pressure Study, Society of Actuaries, 1959

b Dose during the 5 days of optimal control (period 2)

therapy was begun. Patients received doses of lente and soluble insulin $30 \mathrm{~min}$ before breakfast and again at $1400 \mathrm{~h}$ daily. Each patient's average daily dose of insulin is shown in Table 1 . When a normal fasting plasma glucose was attained (after 4-10 days of treatment), 5 days of observations were made while optimal insulin therapy was continued (period 2). As an additional index of glycaemic control $24 \mathrm{~h}$ urinary excretion of glucose was measured daily.

A test meal of $125 \mathrm{~g}$ cooked ground beef was ingested on the second hospital day (on the first day of period 1) following the overnight fast. A butterfly needle was inserted into an antecubital vein and maintained patent by a solution of heparin $(100 \mathrm{U} / \mathrm{ml})$ in $0.154 \mathrm{~mol} / \mathrm{l}$ saline. Samples of venous blood were obtained and placed into heparinised tubes 30,15 and $0 \mathrm{~min}$ before and 5, 10, $20,30,60,120$ and 180 min after the start of the ingestion. The test was repeated on the last day of insulin treatment (period 2) when it was begun $60 \mathrm{~min}$ after the morning dose of insulin. All patients consumed the beef meal over 5-10 min periods. On the morning of beef ingestion, the -15 and 0 min samples were considered that day's fasting (basal) samples and the mean value of these two samples was considered the fasting level. On the other eight mornings of observation, a blood sample was obtained after the overnight fast and before the morning dose of insulin. All samples were placed in ice immediately; the plasma was separated within $2 \mathrm{~h}$ and stored at $-20^{\circ} \mathrm{C}$ until assayed.

\section{Assays}

Plasma PP [4], immunoreactive glucagon (IRG) [5] and immunoreactive insulin (IRI) [6] were measured by double-antibody radioimmunoassays. Standard human PP (lot 615-10543200) and rabbit anti-human PP serum (lot 615-1054B-248-18) were given to us by Dr. Ronald Chance of the Eli Lilly, Indianapolis, Indiana, USA. The glucagon antiserum reacts with the carboxyl-terminal region of glucagon; it reacts negligibly with glucagon-like immunoreactivity of jejunal extracts [5]. Plasma glucose was measured by a hexokinase method using a Gilford 3500 computer-directed spectrophotometer [7]. Urinary glucose was measured by a glucose oxidase method [8] using a Beckman System I Analyser. Radioimmunoassay results were computed using a computer program (RIANAL) [9]. All plasma samples from a patient were analysed in a single PP assay and a single glucagon assay; four assays of each peptide were performed. All data are presented as mean \pm SEM. The effect of insulin treatment upon plasma levels of glucose, PP and IRG was ascertained by comparing the mean of each patient's fasting levels during period 1 with that of period 2 and by comparing total and incremental PP and IRG areas in response to beef meals during periods 1 and 2. As there were eight patients, there were eight pairs of observations for basal levels and for each response area. The statistical comparisons were made by two-tailed $t$-tests for paired or unpaired observations [10].

\section{Results}

\section{Fasting Levels}

Fasting plasma levels of glucose, PP and IRG for each patient and for the group are shown in Table 2. The fasting glucose level of the group was $15.9 \pm$ $1.3 \mathrm{mmol} / 1$ in period 1 and $5.9 \pm 0.4 \mathrm{mmol} / \mathrm{l}$ in period $2(\mathrm{p}<0.0001)$; during period 2 the mean levels of individuals ranged from 4.9 to $6.8 \mathrm{mmol} / 1$. Mean \pm SEM $24 \mathrm{~h}$ urinary glucose was $47 \pm 19 \mathrm{~g}$ in period 1 and $2 \pm 1 \mathrm{~g}$ in period $2(\mathrm{p}<0.05)$.

Fasting plasma PP decreased from $328 \pm 97 \mathrm{pg} /$ $\mathrm{ml}$ in period 1 to $247 \pm 71 \mathrm{pg} / \mathrm{ml}$ during period $2(\mathrm{p}$ $<0.05$ ). Mean fasting PP was lower in five patients, increased in one and remained unchanged in two. Fasting IRG level in period 1 was $95 \pm 11 \mathrm{pg} / \mathrm{ml}$ and in period 2 was $62 \pm 6 \mathrm{pg} / \mathrm{ml}(\mathrm{p}<0.005)$; fasting IRG levels were lower in period 2 than in period 1 in all patients.

Fasting plasma levels of glucose, PP and IRG for each patient on days 1 and 5 (the last day) of period 1 are shown in Table 3; there was no significant difference in the mean levels of glucose, PP or IRG on day 1 compared with day 5 .

\section{Responses to Beef Meal}

During the period 1 beef test plasma glucose declined gradually from the baseline of $16.6 \pm 0.8 \mathrm{mmol} / \mathrm{l}$ to a nadir of $15.0 \pm 1.1 \mathrm{mmol} / \mathrm{l}$ at $180 \mathrm{~min}(\mathrm{p}<0.05)$ 
Table 2. Effect of treatment of Type 2 (insulin independent) diabetes on fasting plasma glucose, pancreatic polypeptide (PP) and immunoreactive glucagon (IRG). Mean \pm SEM fasting plasma levels of glucose, PP and IRG for 5 days of dietary treatment (period 1) and for 5 consecutive days during treatment with diet plus insulin immediately after fasting plasma glucose had been brought into or near the normal range (period 2)

\begin{tabular}{|c|c|c|c|c|c|c|}
\hline \multirow[t]{2}{*}{ Patient } & \multicolumn{3}{|c|}{ Dietary treatment (period 1) } & \multicolumn{3}{|c|}{ Treatment with diet and insulin (period 2) } \\
\hline & $\begin{array}{l}\text { Glucose } \\
(\mathrm{mmol} / \mathrm{l})\end{array}$ & $\begin{array}{l}\mathrm{PP} \\
(\mathrm{pg} / \mathrm{ml})\end{array}$ & $\begin{array}{l}\text { IRG } \\
(\mathrm{pg} / \mathrm{ml})\end{array}$ & $\begin{array}{l}\text { Glucose } \\
(\mathrm{mmol} / \mathrm{l})\end{array}$ & $\begin{array}{l}\mathrm{PP} \\
(\mathrm{pg} / \mathrm{ml})\end{array}$ & $\begin{array}{l}\text { IRG } \\
(\mathrm{pg} / \mathrm{ml})\end{array}$ \\
\hline 1 & $15.4 \pm 0.4$ & $143 \pm 18$ & $116 \pm 6$ & $5.9 \pm 0.4$ & $72 \pm 4$ & $71 \pm 8$ \\
\hline 2 & $13.6 \pm 0.2$ & $18 \pm 4$ & $157 \pm 16$ & $4.9 \pm 0.3$ & $40 \pm 7$ & $77 \pm 12$ \\
\hline 3 & $16.4 \pm 0.4$ & $216 \pm 27$ & $108 \pm 18$ & $5.7 \pm 0.2$ & $198 \pm 28$ & $62 \pm 6$ \\
\hline 4 & $9.3 \pm 0.7$ & $32 \pm 10$ & $91 \pm 14$ & $6.1 \pm 0.4$ & $37 \pm 7$ & $82 \pm 8$ \\
\hline 5 & $21.9 \pm 1.1$ & $569 \pm 89$ & $89 \pm 12$ & $6.3 \pm 0.6$ & $423 \pm 47$ & $52 \pm 10$ \\
\hline 6 & $18.6 \pm 0.3$ & $365 \pm 35$ & $65 \pm 8$ & $6.0 \pm 0.2$ & $368 \pm 23$ & $45 \pm 12$ \\
\hline 7 & $17.4 \pm 0.06$ & $789 \pm 34$ & $54 \pm 7$ & $6.2 \pm 0.6$ & $583 \pm 57$ & $34 \pm 5$ \\
\hline 8 & $14.6 \pm 0.4$ & $491 \pm 78$ & $84 \pm 12$ & $6.8 \pm 0.4$ & $256 \pm 30$ & $75 \pm 10$ \\
\hline Mean & 15.9 & 328 & 95 & 5.9 & 247 & 62 \\
\hline$\pm \mathrm{SEM}$ & 1.3 & 97 & 11 & 0.2 & 71 & 6 \\
\hline \multirow[t]{2}{*}{ p-value } & L. & -1 & & - & & \\
\hline & & L & L & $<0.005$ & 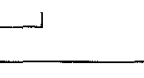 & ــــ \\
\hline
\end{tabular}

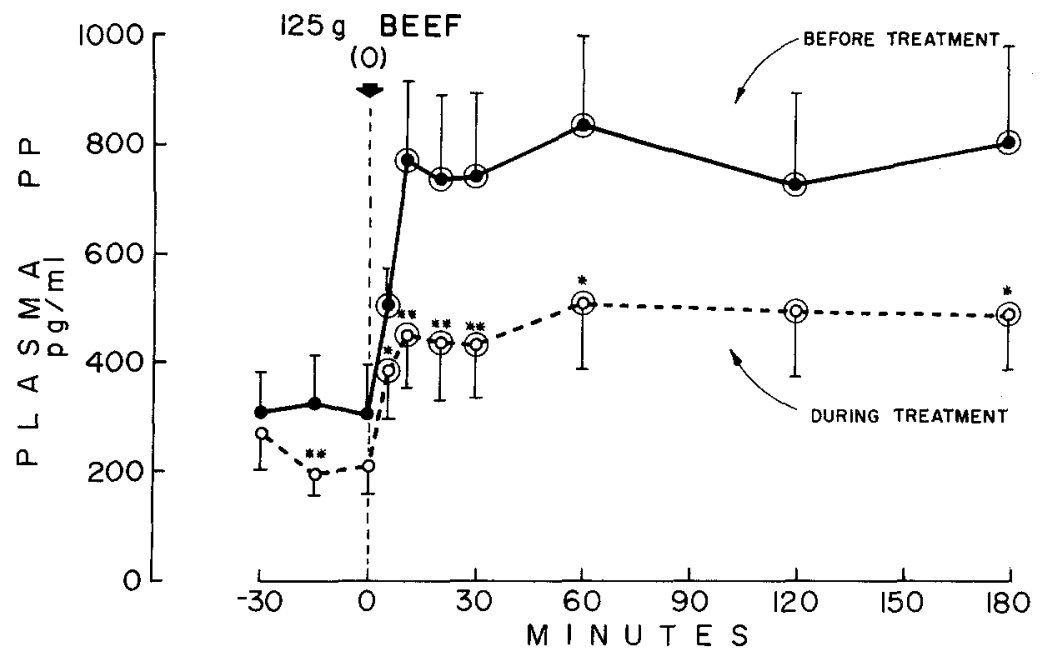

Fig. 1. Effect of the ingestion of test meals of $125 \mathrm{~g}$ cooked ground beef on mean \pm SEM plasma pancreatic polypeptide (PP) levels during treatment with diet (period 1) and during treatment with diet plus insulin (period 2) in eight patients with Type 2 diabetes. Test meals ingested on the first (mean \pm SEM fasting plasma glucose, $16.6 \pm 0.8 \mathrm{mmol} / \mathrm{l}$ ) of the 5 days before insulin treatment and on the last day (mean \pm SEM fasting plasma glucose, $6.3 \pm$ $0.5 \mathrm{mmol} / \mathrm{l}$ ) of treatment with diet plus insulin. Circles around the individual points denote significant differences from basal levels $(p<0.05)$. Asterisks denote significant differences after treatment of diabetes. ${ }^{*} p<0.05$, ** $p<0.02$

Table 3. Plasma levels of glucose, pancreatic polypeptide and immunoreactive glucagon in Type 2 diabetes on days 1 and 5 of period 1 . Mean \pm SEM fasting plasma levels of glucose, PP, and IRG for days 1 and 5 of dietary treatment (period 1)

\begin{tabular}{|c|c|c|c|c|c|c|}
\hline \multirow[t]{2}{*}{ Patient } & \multicolumn{2}{|c|}{$\begin{array}{l}\text { Glucose } \\
(\mathrm{mmol} / \mathrm{l})\end{array}$} & \multicolumn{2}{|c|}{$\begin{array}{l}\text { Pancreatic polypeptide } \\
(\mathrm{pg} / \mathrm{ml})\end{array}$} & \multicolumn{2}{|c|}{$\begin{array}{l}\text { Immunoreactive glucagon } \\
(\mathrm{pg} / \mathrm{ml})\end{array}$} \\
\hline & day 1 & day 5 & day 1 & day 5 & day 1 & day 5 \\
\hline 1 & 16.0 & 16.2 & 137 & 117 & 137 & 112 \\
\hline 2 & 13.5 & 13.1 & 8 & 27 & 165 & 111 \\
\hline 3 & 15.7 & 17.4 & 258 & 267 & 120 & 81 \\
\hline 4 & 11.3 & 8.7 & 47 & 15 & 122 & 98 \\
\hline 5 & 17.8 & 23.5 & 375 & 904 & 79 & 134 \\
\hline 6 & 18.6 & 17.8 & 365 & 300 & 65 & 39 \\
\hline 7 & 17.6 & 17.2 & 715 & 760 & 52 & 37 \\
\hline 8 & 13.3 & 14.7 & 397 & 486 & 94 & 107 \\
\hline Mean & 15.4 & 16.1 & 288 & 360 & 104 & 90 \\
\hline \pm SEM & 0.9 & 1.5 & 81 & 118 & 14 & 13 \\
\hline $\mathrm{p}$-value & \multicolumn{2}{|c|}{ NS } & \multicolumn{2}{|c|}{ NS } & \multicolumn{2}{|c|}{ NS } \\
\hline
\end{tabular}




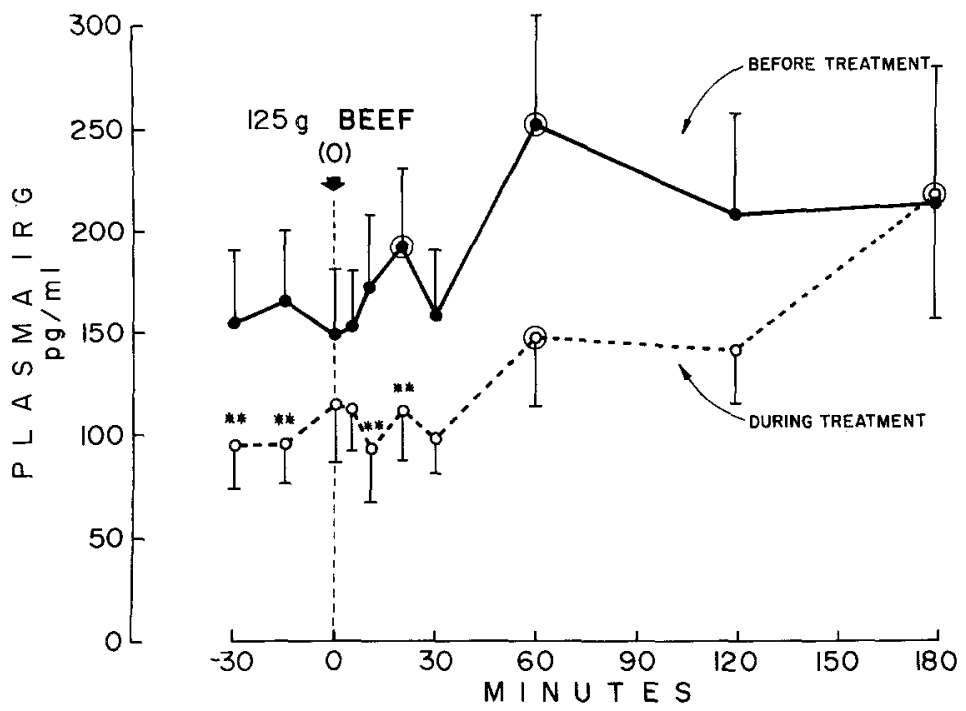

Fig. 2. Effect of the ingestion of test meals of $125 \mathrm{~g}$ cooked ground beef on mean \pm SEM plasma immunoreactive glucagon (IRG) levels during periods 1 and 2. See also legend for Fig. 1

Table 4. Effect of treatment of Type 2 diabetes on response of plasma pancreatic polypeptide and immunoreactive glucagon to ingestion of beef. Plasma PP and IRG response areas following ingestion of $125 \mathrm{~g}$ cooked ground beef during dietary treatment (period 1 ) and during optimal treatment with insulin plus diet (period 2) in eight patients

\begin{tabular}{|c|c|c|c|c|}
\hline & \multicolumn{2}{|c|}{ Pancreatic polypeptide (ng. $\min ^{-1} \mathrm{ml}^{-1}$ ) } & \multicolumn{2}{|c|}{ Immunoreactive glucagon (ng. $\min ^{-1} \mathrm{ml}^{-1}$ ) } \\
\hline & Total area & Incremental area & Total area & Incremental area \\
\hline Period 1 & $137 \pm 26$ & $81 \pm 9$ & $38 \pm 9$ & $9 \pm 5$ \\
\hline Period 2 & $86 \pm 18$ & $50 \pm 15$ & $26 \pm 15$ & $7 \pm 3$ \\
\hline p-value & $<0.01$ & $<0.005$ & $<0.05$ & $\mathrm{NS}$ \\
\hline
\end{tabular}

Results are expressed as areas above zero plasma levels and designated total area and as areas above the basal level at the start of the ingestion of beef (average of -15 and 0 min plasma levels) and designated incremental area

(levels not shown). During the beef test of period 2 plasma glucose decreased from $6.3 \pm 0.5$ to $4.9 \pm$ $0.5 \mathrm{mmol} / 1$ at $180 \mathrm{~min}(\mathrm{p}<0.05)$ and was significantly lower at all time points than during the period 1 test $(\mathrm{p}<0.0001)$. Plasma IRI values $(\mathrm{mU} / 1)$ of the period 1 and period 2 beef tests respectively, were: at 0 min $8 \pm 2$ versus $21 \pm 2 ; 30 \min 12 \pm 2$ versus 26 $\pm 3 ; 60 \min 22 \pm 5$ versus $31 \pm 4 ; 120 \min 23 \pm 4$ versus $35 \pm 3 ; 180 \min 19 \pm 3$ versus $32 \pm 2$.

Mean plasma PP levels for periods 1 and 2 beef tests are shown in Fig. 1. During the period 2 test, mean plasma levels of PP at $-15,5-60$ and $180 \mathrm{~min}$ and the mean maximal rise ( $746 \pm 144$ versus $474 \pm$ $99 \mathrm{pg} / \mathrm{ml}, \mathrm{p}<0.005$ ) were significantly lower than during the period 1 test. During the period 2 test the mean total PP area and the mean incremental PP area decreased significantly (Table 4 ); these areas decreased in seven of the eight patients.

During the period 1 beef ingestion plasma IRG (Fig. 2) levels rose significantly from a basal level of $157 \pm 34$ to $192 \pm 39 \mathrm{pg} / \mathrm{ml}$ at $20 \mathrm{~min}$; the peak of $253 \pm 53 \mathrm{pg} / \mathrm{ml}$ was reached at $60 \mathrm{~min}$. During the period 2 test mean plasma IRG did not rise significantly until $60 \mathrm{~min}$; the peak mean level occurred at $180 \mathrm{~min}$. Mean levels of IRG were significantly lower than in the period 1 test at $-30,-15,10$ and 20 $\mathrm{min}$. The total IRG area decreased significantly during period 2 (Table 4).

\section{Discussion}

This investigation has shown that treatment of Type 2 (insulin independent) diabetes mellitus which brought mean fasting plasma glucose into the normal range was associated with a significant decrease in the mean plasma levels of PP. Before treatment with insulin, basal plasma levels of PP were supernormal in half of the patients, that is, $>$ mean +2 SD of levels of healthy subjects in the same decades of age [4]; during treatment the fasting level of PP fell in five of the eight patients and the plasma PP response to the test meal was decreased in seven of the patients. The latter finding suggests that the effects of 
the treatment include a decrease in the rate of secretion of PP. The mechanism by which this could happen was not the subject of study. It may relate to a change (improvement) in the metabolism of the PP cell resulting from the effects of insulin treatment. Such effects might include an improved recognition of glucose by the PP cell or an increase in metabolism of glucose by the PP cell. The diet treatment per se could have played a role in the lowering of mean basal and stimulated plasma levels of PP perhaps through a change in gastrointestinal function; there was, however, no difference in the mean fasting levels of PP or glucose of the first day as compared with day 5 of period 1 when diet was the only treatment. Improvement in impaired renal function [11, 12] would be expected to lower plasma levels of PP, but none of the patients had evidence of renal impairment.

During treatment there was a significant decrease in the mean fasting plasma level of IRG and in the mean total IRG response to the beef meal. The individual fasting levels of IRG which were normal [4] in period 1 decreased in each of the eight patients; the response to the meal decreased in five of the eight patients. Perhaps the much smaller plasma IRG than PP response to the meal made it more difficult to show consistently the effects of treatment upon the IRG response. Others found that the IRG response to protein meals was not lowered in Type 2 diabetes even when supraphysiological doses of insulin were infused overnight and supplemental injections of insulin were given shortly before the meals $[13,14]$. The lowering of the IRG response to protein meals in the present study may be due to the longer preceding period of insulin treatment.

The treatment of patients with Type 2 diabetes resulted therefore in changes in plasma PP and IRG which qualitatively were similar. Treatment with diet plus insulin may have improved by the same mechanism abnormal metabolism of the PP cell and the A cell (secondary to the diabetic state) which appeared to have led to exaggerated hormonal responses to protein meals. Analogies concerning PP and A cell secretory functions must be made with circumspection. Differences in mechanisms of release of PP and IRG in healthy subjects are suggested for example by the differential effects of arginine infusion; infusion of arginine is without effect upon plasma levels of PP but induces marked increases in IRG $[1,2]$.

Among the patients of this study basal plasma levels of PP correlated with age $(r=0.78 ; p=0.02)$ and when corrected for the effects of age the PP levels correlated with glucose levels of the period before insulin treatment was begun $(\mathrm{r}=0.69 ; \mathrm{p}=$ 0.05 ). The findings are in concert with earlier find- ings that plasma levels of PP correlate with age in Type 2 diabetes [2] and in healthy subjects [2, 4, 15-17]. In three of the four older patients period 1 basal levels of PP were supernormal and in the fourth it was nearly so. Perhaps duration of diabetes or age interacting with diabetes relates to these findings in the older subjects. There was no evidence of an effect of adiposity upon fasting plasma levels of PP $[18,19]$.

The physiological significance of a reduction in fasting and post-prandial plasma levels of PP remains to be delineated. When human PP is infused in healthy subjects so as to raise PP to levels similar to those which occur post-prandially the rate with which trypsin appears in duodenal fluid is reduced [20]. The lowering of post-prandial levels of PP as achieved in these patients as a consequence of the control of diabetes could be expected to increase the rate with which trypsin appears in duodenal juice and to aid in the assimilation of protein.

Acknowledgements. We thank Dr. S. S. Fajans for his criticism of this work and thank R.C. Crowther, and Diane Lomatch for assistance in data management and statistical analyses. Work supported in part by US Public Health Service grants AM-02244, AM-00888, AM-20572 and TI AM-05001, National Institute of Arthritis, Metabolism and Digestive Diseases; RR-42, General Clinical Research Program; 5P11-GM15559, National Institute of General Medical Sciences; by the American Diabetes Association - Michigan Affiliate; The Upjohn Company, Kalamazoo, Michigan; Pfizer, New York, and the Eli Lilly Company, Indianapolis, Indiana.

\section{References}

1. Floyd JC Jr, Fajans SS, Pek S (1976) Regulation in healthy subjects of the secretion of human pancreatic polypeptide, a newly recognized pancreatic islet polypeptide. Trans Assoc Am Physicians 89: 46-158

2. Floyd JC Jr., Fajans SS, Pek S, Chance RE (1977) A newly recognized pancreatic polypeptide; plasma levels in health and disease. Recent Prog Horm Res 33: 519-570

3. Adrian TE, Bloom SR, Besterman HS, Bryant MG (1978) Pancreatic polypeptide - physiology and pathology. In: Bloom SR (ed) Gut hormones. Churchill Livingstone, Edinburgh London New York, pp 254-260

4. Berger D, Crowther RC, Floyd JC Jr, Pek S, Fajans SS (1978) Effect of age on fasting plasma levels of pancreatic hormones in healthy subjects. J Clin Endocrinol Metab 47: 1183-1189

5. Pek S (1978) Glucagon and insulin. In: Rothfeld B (ed) Nuclear medicine: Endocrinology. JB Lippincott, Philadelphia, pp 122-140

6. Hayashi M, Floyd JC Jr, Pek S, Fajans SS (1977) Insulin, proinsulin, glucagon and gastrin in pancreatic tumors and in plasma of patients with organic hyperinsulinism. J Clin Endocrinol Metab 44: 681-694

7. Bondar RJL, Mead D (1974) Evaluation of glucose-6-phosphate dehydrogenase from leuconostoc mesenteroides in the hexokinase method for determining glucose in serum. Clin Chem 20: 586-590

8. Froesch ER, Renold AE (1956) Specific enzymatic determination of glucose in blood and urine using glucose oxidase. Diabetes 5: 1-6 
9. Duddelson WG, Midgley AR Jr, Niswender GD (1972) Computer program sequence for analysis and summary of radioimmunoassay data. Comput Biomed Res 5: 205-217

10. Afifi AA, Azen SP (1972) Statistical analysis: A computer oriented approach. Academic Press, New York

11. Hällgren R, Lundqvist G, Chance RE (1977) Serum levels of human pancreatic polypeptide in renal disease. Scand J Gastroenterol 12: 923-927

12. Boden G, Master RWP, Salvaggio A, Rudnick MR (1978) Elevation of human pancreatic polypeptide in chronic renal failure. Kidney Int 14: 737

13. Unger RH, Raskin P, Srikant CB, Orci L (1977) Glucagon and the A cells. Recent Prog Horm Res 33: 477-517

14. Aydin I, Raskin P, Unger RH (1977) Role of insulin lack in the abnormal glucagon response in human diabetes. Clin Res 25: $31 \mathrm{~A}$

15. Schwartz TW, Stenquist B, Olbe L, Stadil F (1979) Synchronous oscillations in the basal secretion of pancreatic polypeptide and gastric acid. Depression by cholinergic blockade of pancreatic polypeptide concentrations in plasma. Gastroenterology 76: 14-19

16. Taylor IL, Rotter J, Walsh JH, Passaro E Jr (1978) Is pancreatic polypeptide a marker for Zollinger-Ellison syndrome? Lancet I: $845-848$
17. Track N, Watters LM, Gauldie J (1979) Motilin, human pancreatic polypeptide (hPP) and gastrin plasma concentrations in fasting subjects. Clin Biochem 12: 109-117

18. Marco J, Zulueta MA, Correas I, Villanueva MI (1980) Reduced pancreatic polypeptide secretion in obese subjects. $\mathrm{J}$ Clin Endocrinol Metab 50: 744-747

19. Lassman V, Vague P, Vialettes B, Simon MC (1980) Low plasma levels of pancreatic polypeptide in obesity. Diabetes 29: $428-430$

20. Greenberg GR, Adrian TE, Baron JH, McCloy RF, Chadwich VS, Bloom SR (1980) Inhibition of pancreas and gall bladder by pancreatic polypeptide. Lancet I: $1280-1282$

Received: 29 July 1980 ,

and in revised form: 1 April 1981

Dr. J. C. Floyd, Jr.

University of Michigan

C7009 Outpatient Building

Box 002

Ann Arbor, MI 48109, USA 